https://doi.org/10.5817/NR2019-2-7

\title{
Своевременная и полезная книга рекомендаций в помощь учителю
}

ROZBOUDOVÁ, L., KONEČNÝ, J.: Moderní didaktika ruštiny jako dalšího cizího jazyka: jazykové prostredky = Современная дидактика русского языка как второго иностранного: языковые средства. Praha: Univerzita Karlova, Nakladatelství Karolinum, 2018. ISBN 978-83-8088-136-5.

Если мы сегодня будем учить студентов так, как мы их учили вчера, мы украдем у них завтра. Джон Дьюи

В связи с процессом глобализации, тесно связанным кроме прочего с расширением уровней и сфер международного общения и формированием межкультурных контактов, происходит смена образовательной парадигмы, т. е. наблюдаются существенные изменения в процессе образования, что заставляет и методистов, и преподавателей немедленно реагировать на данные импульсы. Особенно это касается изучения иностранных языков, которые считаются одним из важнейших средств общения в нашем глобализированном мире, и русский язык как иностранный не является исключением.

Методика обучения русскому языку в Чешской Республике имеет свою историю, несомненно, оказавшую влияние на ее дальнейшее развитие [ROZBOUDOVÁ, KONEČNÝ 2018, 11-12]. На данном этапе возникла потребность в создании современного пособия для учителей русского языка как иностранного, которое было бы направлено на решение актуальных вопросов обучения аудитории чешских студентов. Последнее пособие подобного характера было издано в Чешской Республике 15 лет тому назад, с тех пор произошли и продолжают происходить существенные изменения в области лингводидактики. Методические пособия и рекомендации иногда являются частью учебно-методических комплексов, но увы, они направлены только на конкретное пособие и не отражают целостную картину развития лингводидактики на современном этапе, не всегда учитывают актуальные тенденции обучения. Как известно, количество учебников по русскому языку как иностранному на русском рынке стремительно растет, но ориентированы они в большинстве случаев на различный контингент студентов, а не на конкретный контингент и родной язык студентов. На чешском рынке на данный момент предлагаются на 
выбор определенные серии современных учебников, расчитанных на чешского студента, и учителю - не только будущему, но и уже состоявшемуся - необходимо уметь ориентироваться в данном количестве предложений и выбрать соответствующий учебный комплекс для своих учеников. Рекомендуемая публикация по лингводидактике, авторами которой являются Ленка Розбоудова и Якуб Конечны, поможет справиться с данными задачами, не только предлагая обзор требований к обучению русскому языку, приведенных в обязателыных куррикулумных документах чешской образовательной системы, и определяя место русского языка на современном этапе обучения, но и занимаясь лингводидактическими вопросами характеристики, использования и выбора учебно-методических комплексов по русскому языку как иностранному. Одним из главных преимуществ публикации, вне всякого сомнения, является то, что основной опорой для ее создания послужили два релевантных принципа: учет чешского языка как родного языка учащегося и учет специфики обучения русскому языку как второму иностранному.

Задуманный авторами трехтомный комплекс под названием «Современная дидактика русского языка как второго иностранного», безусловно, будет шагом вперед в дальнейшем развитии чешской лингводидактики и верно послужит учителю, преподающему русский язык как иностранный вне языковой (русской) среды в решении ключевых задач обучения и формировании «межкультурной (социокультурной, интеркультурной) коммуникативной компетенции» [ROZBOUDOVÁ, KONEČNÝ 2018, 19].

На данный момент был издан первый том публикации «Современная дидактика русского языка как второго иностранного: языковые средства», посвященный вопросам методики обучения языковым средствам, которые, по мнению авторов, оправданно считаются одним из важных аспектов при обучении иностранному языку. В монографии подробным образом на теоретическом уровне рассмотрены основные аспекты работы с лексическими, фонетическими, грамматическими, графическими и орфографическими языковыми средствами, а именно: требования к обучению языковым средствам и их место в контексте обучения в чешской образовательной среде, знакомство с языковыми средствами конкретного характера, закрепление и повторение, а также контроль и оценка владения языковыми средствами. Структура книги представлена в виде девяти взаимосвязанных частей, последовательно охватывающих все основные моменты, касающиеся методики обучения чешских студентов языковым средствам русского как второго иностранного на современном этапе. Авторам удалось скомбинировать теоретические основы с практической реализацией процесса обучения, опираясь при этом и на личный опыт. 
В своей монографии авторы обоснованно придают особое значение обучению языковым средствам в первую очередь лексического и фонетического характера, считая их самыми важными в связи с решением коммуникативных задач, но нисколько не умаляя при этом позицию остальных средств языка, тесно связанных с лексикой и фонетикой. Здесь, однако, трудно согласиться с неточным использованием авторами понятия языковые средства для обозначения аспектов языка (уровней языка, разделов лингвистики), таких как лексика, фонетика, грамматика, графика и т. д., напр.: «... главы ... посвящены отдельным языковым средствам: лексике, фонетике, грамматике, графике и орфографии» [ROZBOUDOVÁ, KONEČNÝ 2018, 12]. В данном случае более подходящими были бы термины лексические, фонетические, грамматические и т. д. языковые средства.

Достоинством публикации является то, что авторы подошли к изложению вопросов методики комплексно, включая определение основных лингводидактических понятий (метод и технология обучения; цель обучения; знания, умения и навыки; коммуникативная компетенция и др.), взаимосвязь лингводидактики с педагогикой и общей дидактикой, с психологией, определение специфик обучения близкородственному русскому языку чешских учащихся и т.д. Отдельная глава предназначена объяснению отношений между понятиями речевые умения и языковые средства, понимание которых необходимо для осуществления «комплексности обучения всем языковым средствам и всем речевым умениям» [ROZBOUDOVÁ, KONEČNÝ 2018, 44-45].

Книга, несомненно, будет первым научным трудом, отражающим современные тенденции в развитии лингводидактики, и ценным и незаменимым источником по лингводидактике не только для будущих учителей, обучающихся по специальности учитель русского языка и литературы в средней школе, но и для уже имеющих опыт преподавателей РКИ в чешских школах. К сожалению, присутствующие в тексте монографии языковые недочеты - грамматические и стилистические ошибки, опечатки [ROZBOUDOVÁ, KONEČNÝ 2018, 25, 31] - изрядно портят общее восприятие ценного содержания пособия, например, «... они всегда направленны на...» [ROZBOUDOVÁ, KONEČNÝ 2018, 12], «A. А. Миролюбова» [ROZBOUDOVÁ, KONEČNÝ 2018, 16] (академик-мужчина), «...намного лучше, чем любим другим иностранным языком» [ROZBOUDOVÁ, KONEČNÝ 2018, 28], «согласно с государственными стандартами...» [ROZBOUDOVÁ, KONEČNÝ 2018, 36], «о всем комплексе»[ROZBOUDOVÁ, KONEČNÝ 2018, 41], «при далнейшей тренировке» [ROZBOUDOVÁ, KONEČNÝ 2018, 50], использование глагола наметить вместо отметить: «уже было намечено выше...» [ROZBOUDOVÁ, KONEČNÝ 2018, 29, 40 и т. д.] и др. 
Забегая вперед, необходимо отметить, что планируемые вторую и третью части монографии авторы намерены посвятить не менее важным аспектам речевым умениям и актуальным вопросам современного обучения русскому языку. В качестве приложения к данной научной публикации авторы предполагают создание электронных пособий, доступных впоследствии в открытом режиме, что, несомненно, может только порадовать всех, кого интересует лингводидактика и особенности эффективного обучения иностранному языку на современном этапе.

Хотелось бы поблагодарить авторов за принятие такого серьезного решения создание комплексного пособия по лингводидактике в чешской среде; одновременно хотелось бы порекомендовать авторам обратить должное внимание на вышеперечисленные замечания, касающиеся языкового уровня излагаемого материала, и пожелать им терпения, вдохновения и творческих успехов в их нелегком, но, безусловно, для всех нас полезном труде.

Татьяна Занько

\section{Библиография:}

ROZBOUDOVÁ, L., KONEČNÝ, J. (2018): Moderní didaktika ruštiny jako dalšího cizího jazyka: jazykové prostředky = Sovremennaja didaktika russkogo jazyka kak vtorogo inostrannogo: jazykovyje sredstva. Praha.

https://doi.org/10.5817/NR2019-2-8

\section{Ztracený svět, drásavá nostalgie}

ФРИЗМАН, Л. Г.: В кругах литературоведов. Мемуарные очерки. Москва-Санкт-Петербург: Нестор-История, 2017.

Leonid Frizman (1935-2018) byl významný sovětský a ruský literární vědec. Jeho studie - většinou v časopise Voprosy literatury - a knihu o ruské elegii jsem četl v 7o. letech minulého století. Frizman patří k obrovské skupině ruských literárních vědců, především sovětského období, židovského původu, kteří vlastně utvářeli kvalitativní charakter sovětské a ruské literární vědy a také působili jako svérázný tmel mezi různými etniky SSSR. Vzhledem ke skrytému i otevřenému antisemitismu, jenž byl východoslovanskému prostředí (ale stejně nebo více i jiným prostředím ve střední a západní Evropě) tradičně vlastní, neměli lehký život: i o tom Frizman v této 